\title{
Free tropospheric peroxyacetyl nitrate (PAN) and ozone at Mount Bachelor: potential causes of variability and timescale for trend detection
}

\author{
E. V. Fischer ${ }^{1}$, D. A. Jaffe ${ }^{1,2}$, and E. C. Weatherhead ${ }^{3}$ \\ ${ }^{1}$ Department of Atmospheric Sciences, University of Washington, Seattle, WA, USA \\ ${ }^{2}$ Science \& Technology Program, University of Washington-Bothell, Bothell, WA, USA \\ ${ }^{3}$ Cooperative Institute for Research in Environmental Science, University of Colorado at Boulder, Boulder, CO, USA
}

Received: 26 October 2010 - Published in Atmos. Chem. Phys. Discuss.: 4 February 2011

Revised: 9 May 2011 - Accepted: 25 May 2011 - Published: 20 June 2011

\begin{abstract}
We report on the first multi-year springtime measurements of PAN in the free troposphere over the US Pacific Northwest. The measurements were made at the summit of Mount Bachelor $\left(43.979^{\circ} \mathrm{N}, 121.687^{\circ} \mathrm{W} ; 2.7 \mathrm{~km}\right.$ a.s.1.) by gas chromatography with electron capture detector during spring 2008, 2009 and 2010. This dataset provides an observational estimate of the month-to-month and springtime interannual variability of PAN mixing ratios in this region. Springtime seasonal mean (1 April-20 May) PAN mixing ratios at Mount Bachelor varied from 100 pptv to $152 \mathrm{pptv}$. The standard deviation of the three seasonal means was $28 \mathrm{pptv}$, $21 \%$ of the springtime mean. We summarize the interannual variability in three factors expected to drive PAN variability: biomass burning, transport efficiency over the central and eastern Pacific, and transport temperature.

Zhang et al. (2008) used the GEOS-Chem global chemical transport model to show that rising Asian $\mathrm{NO}_{\mathrm{x}}$ emissions from 2000 to 2006 resulted in a relatively larger positive trend in PAN than $\mathrm{O}_{3}$ over western North America. However the model results only considered monotonic changes in Asian emissions, whereas other factors, such as biomass burning, isoprene emissions or climate change can induce greater variability in the atmospheric concentrations and thus extend the time needed for trend detection. We combined the observed variability in PAN and $\mathrm{O}_{3}$ at Mount Bachelor with a range of possible future trends in these species to determine the observational requirements to detect such trends. Though the relative increase in PAN is expected to be larger than that of $\mathrm{O}_{3}$, PAN is more variable. If PAN mixing ratios are currently increasing at a rate of $4 \%$ per year due to rising Asian
\end{abstract}

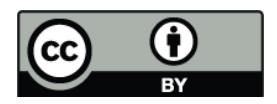

Correspondence to: E. V. Fischer (efischer@atmos.washington.edu) emissions, we would detect a trend with 13 years of measurements at a site like Mount Bachelor. If the corresponding trend in $\mathrm{O}_{3}$ is $1 \%$ per year, the trends in $\mathrm{O}_{3}$ and PAN would be detected on approximately the same timescale.

\section{Introduction}

Ozone $\left(\mathrm{O}_{3}\right)$ is regulated in the US under the Clean Air Act. Urban concentrations of $\mathrm{O}_{3}$ have been decreasing, but a significant fraction of the US population $(\sim 40 \%)$ is still exposed to harmful concentrations of this pollutant (Bell et al., 2004; Hubbell et al., 2005). The US Environmental Protection Agency (EPA) revised the 8-hour $\mathrm{O}_{3}$ standard downward to $75 \mathrm{ppbv}$ in 2008. If a threshold for $\mathrm{O}_{3}$ health impacts exists, it is well below this 75 ppbv (NRC, 2008), so a lower standard is currently under consideration. As background concentrations of this species rise, larger domestic emission reductions will be required to offset the incremental contribution from non-domestic anthropogenic or natural sources (NRC, 2010; Jacob et al., 1999).

$\mathrm{O}_{3}$ concentrations have increased in the lower atmosphere since the late 1800s (Staehelin et al., 1994). The increase is primarily attributed to a rise in precursor $\mathrm{NO}_{\mathrm{x}}\left(\mathrm{NO}+\mathrm{NO}_{2}\right)$ emissions from widespread industrialization and increased biomass burning, which caused tropospheric $\mathrm{O}_{3}$ production to double (Horowitz, 2006). East Asia is currently the fastest growing source of $\mathrm{O}_{3}$ precursors, and emissions are projected to continue to increase substantially through 2020 (Ohara et al., 2007). $\mathrm{O}_{3}$ concentrations in the Asian export region are rising rapidly (Lee et al., 1998), and there is evidence that the trend is larger toward the upper end of the $\mathrm{O}_{3}$ distribution (Tanimoto, 2009). The impact of Asian emissions of $\mathrm{O}_{3}$

Published by Copernicus Publications on behalf of the European Geosciences Union. 
precursors on North American $\mathrm{O}_{3}$ concentrations is twofold. $\mathrm{O}_{3}$ has a sufficient lifetime during spring $(\sim 1$ month $)$ that $\mathrm{O}_{3}$ exported directly from the Asian boundary layer (BL) can have an impact on downwind regions (Heald et al., 2003; Jaeglé et al., 2003). $\mathrm{O}_{3}$ is also produced in-transit from the export of peroxyacetyl nitrate (PAN) (Jaeglé et al., 2003).

There are multiple lines of evidence that springtime $\mathrm{O}_{3}$ concentrations are increasing over western North America (Cooper et al., 2010; Chan and Vet, 2010; Parrish et al., 2009; Jaffe et al., 2003; Jaffe and Ray, 2007; NRC, 2010; Parrish et al., 2004). The most recent analysis by Cooper et al. (2010) showed a strong increase in lower free tropospheric (FT) springtime $\mathrm{O}_{3}$ mixing ratios from 1995 to 2008. They used a retroplume analysis to show that the rate of increase in $\mathrm{O}_{3}$ mixing ratios is greatest in air masses directly transported from Asia. Parrish et al. (2009) also showed a positive trend $\left(0.46 \mathrm{ppbv} \mathrm{year}^{-1}\right)$ in springtime onshore flow of marine air along the North American west coast. However $\mathrm{O}_{3}$ concentrations above the boundary layer (BL) at Trinidad Head, California do not show a significant change over the last 10 years (Oltmans et al., 2008). As noted by Jaffe and Ray (2007), the low frequency of ozonsondes limits the statistical power of this dataset. Detection of $\mathrm{O}_{3}$ changes in the northeastern Pacific FT is challenging because consistent observations in this region are sparse. While most observational studies have attributed the increase in $\mathrm{O}_{3}$ to rising Asian emissions, global chemical transport models underestimate the observed increases in $\mathrm{O}_{3}$ (Fiore et al., 2009), undermining our confidence in the attribution.

There is evidence that that $\mathrm{O}_{3}$ production driven by the thermal decomposition of PAN can be significant over the eastern Pacific (Kotchenruther et al., 2001b; Fischer et al., 2010b; Yienger et al., 2000; Hudman et al., 2004). Peroxycarboxylic nitric anhydrides (PANs, chemical formula: $\left.\mathrm{RC}(\mathrm{O}) \mathrm{OONO}_{2}\right)$ are formed in the atmosphere through the same complex photochemistry that forms $\mathrm{O}_{3}$ (Roberts, 2007). The formation of PANs involves several stages of the oxidation of non-methane volatile organic compounds (NMVOCs). Most NMVOCs can serve as PAN precursors though the yield varies (Roberts, 2007). The immediate precursors are the oxidation intermediates acetaldehyde $\left(\mathrm{CH}_{3} \mathrm{CHO}\right)$, acetone $\left(\mathrm{CH}_{3} \mathrm{C}(\mathrm{O}) \mathrm{CH}_{3}\right)$, and methylglyoxal $\left(\mathrm{CH}_{3} \mathrm{COCHO}\right)$. Methylglyoxal is an oxidation product of isoprene (Paulot et al., 2009), a very reactive biogenic VOC with a temperature and sunlight dependent emission rate (Guenther et al., 2006). The most abundant peroxycarboxylic nitric anhydride is commonly called peroxyacetyl nitrate (PAN, chemical formula: $\mathrm{CH}_{3} \mathrm{C}(\mathrm{O}) \mathrm{OONO}_{2}$ ).

PAN is often the most abundant member of the odd nitrogen $\left(\mathrm{NO}_{\mathrm{y}}\right)$ family in the $\mathrm{FT}$, and it is present at mixing ratios ranging from a few pptv in the remote marine atmosphere to several ppbv in polluted urban environments and biomass burning plumes (Singh and Salas, 1986; Ridley et al., 1990; Singh et al., 1990; Singh et al., 1998). The lifetime of PAN is strongly dependent on air mass temperature. PAN is stable in the mid-troposphere, which allows the compound to be transported on a hemispheric scale and serve as a reservoir for reactive nitrogen. The main loss process for PAN below $\sim 7 \mathrm{~km}$ is via thermal decomposition $\left(\mathrm{CH}_{3} \mathrm{C}(\mathrm{O}) \mathrm{O}_{2} \mathrm{NO}_{2} \rightarrow\right.$ $\mathrm{CH}_{3} \mathrm{C}(\mathrm{O}) \mathrm{O}_{2}+\mathrm{NO}_{2}$ ) (Talukdar et al., 1995). The dissociative lifetime of PAN is longer than 1 month at temperatures characteristic of the mid-troposphere in spring, but much shorter, on the order of $1 \mathrm{~h}$, at $20^{\circ} \mathrm{C}$. PAN decomposes within subsiding air masses to release $\mathrm{NO}_{\mathrm{x}}$ in remote areas, and measurements of PAN and $\mathrm{NO}_{\mathrm{x}}$ in the remote troposphere support this view (Kotchenruther et al., 2001b; Singh and Salas, 1986; Fischer et al., 2010b).

Our ability to detect trends in environmental data depends on the size of the trend, the magnitude of the variability, and the autocorrelation of the observations (Weatherhead et al., 1998; Weatherhead et al., 2002; Tiao et al., 1990). To confidently detect a trend in a trace gas, it must be large relative to both the natural variability and to the measurement uncertainty, or alternatively one needs many years of observations.

Jaffe et al. (2007) hypothesized that the impact of rising Asian $\mathrm{NO}_{\mathrm{x}}$ emissions on US air quality should be detected more quickly in PAN than $\mathrm{O}_{3}$ due to the larger relative change. Attribution of a trend in this species is also less complicated because there is a smaller background. Based on the GEOS-Chem calculation for the years 2000 and 2006, we expect a relatively larger percentage increase in PAN over the eastern Pacific. The expected increase in PAN concentrations $\left(\sim 3-5 \%\right.$ year $\left.^{-1}\right)$ due to rising Asian emissions is larger than that expected for $\mathrm{O}_{3}\left(\sim 0.5-1 \%\right.$ year $\left.^{-1}\right)$ (Zhang et al., 2008). Therefore it may take less time to detect a trend in PAN than a trend in $\mathrm{O}_{3}$ (Jaffe et al., 2007). The current set of PAN observations over the northeast Pacific are discontinuous and made from a range of platforms (Kotchenruther et al., 2001b; Nowak et al., 2004; Roberts et al., 2004; Wolfe et al., 2007; Zhang et al., 2008; Kotchenruther et al., 2001a). Thus, these observations are insufficient to establish a trend in this constituent or to quantify the true variability.

Here we present the first consistent multi-year springtime measurements of PAN in the free troposphere over the US Pacific Northwest. The measurements were made at the summit of Mount Bachelor $\left(43.979^{\circ} \mathrm{N}, 121.687^{\circ} \mathrm{W}\right.$; $2.7 \mathrm{~km}$ a.s.l.) by gas chromatography with electron capture detector during spring 2008, 2009, and 2010. These observations will be an important benchmark for future observational campaigns targeting the influence of imported $\mathrm{O}_{3}$ precursors on air quality in this region. We also address the observational requirements for detecting a rise in $\mathrm{O}_{3}$ or PAN due to changes in Asian precursor emissions. 


\section{Methods}

\subsection{PAN measurements}

Mount Bachelor Observatory (MBO) is located on the summit of a dormant volcano in central Oregon $\left(43.98^{\circ} \mathrm{N}\right.$ $121.7^{\circ} \mathrm{W}, 2763 \mathrm{~m}$ a.s.l.). The site was established in 2004. Observations from MBO have been used to explore the transport of $\mathrm{CO}, \mathrm{O}_{3}$, reactive nitrogen, aerosols, and mercury from Asia to the US (Fischer et al., 2010a,b, 2009; Reidmiller et al., 2010; Jaffe et al., 2005; Weiss-Penzias et al., 2006). PAN was measured at MBO by gas chromatography with electron capture detector (ECD) during four campaigns: 3 April-18 June 2008, 30 August-7 October 2008, 26 March-20 May 2009, and 23 March-25 May 2010.

The sampling inlet is located on the roof of the Mount Bachelor summit lift building, and the instruments are located in two temperature controlled rooms within the building, situated approximately $15 \mathrm{~m}$ lower than the inlet. The gas phase species, including $\mathrm{CO}, \mathrm{O}_{3}$, and PAN, were sampled through a $1 / 4^{\prime \prime}$ internal diameter PFA Teflon line, with a $1 \mu \mathrm{m}$ Teflon filter located at the inlet. All instruments were connected to the line through a common Teflon manifold, and flow through the line was $\sim 141 \mathrm{~min}^{-1}$ resulting in an inlet residence time of $\sim 2 \mathrm{~s}$.

PAN was measured with a custom gas chromatograph with an electron capture detector (ECD). A detailed description of this instrument is presented in Fischer et al. (2010b). Briefly, we used a 15 m Restek Rtx-200 ms ( $1 \mu \mathrm{m}$ film thickness, $0.53 \mathrm{~mm}$ ID) capillary column at $20^{\circ} \mathrm{C}$, and a Shimadzu Mini-2 ECD at $40^{\circ} \mathrm{C}$. The carrier gas and make up gas were ultra-high purity (UHP) helium (He) flowing at $\sim 25 \mathrm{ml} \mathrm{min}^{-1}$ and UHP $\mathrm{N}_{2}$ flowing through the ECD at 2$3 \mathrm{ml} \mathrm{min}{ }^{-1}$. Samples $(1.5 \mathrm{ml})$ were injected every $10 \mathrm{~min}$. Following Flocke et al. (2005), the sample loop and all connecting tubing was $1 / 16^{\prime \prime}$ PEEK. The air masses encountered at MBO have a similar range of water vapor mixing ratios to those sampled during aircraft campaigns, therefore the He was humidified using a hydrated salt cartridge which minimized loss of PAN in the column, valve and connecting tubing (Flocke et al., 2005). This cartridge was changed monthly.

We used a photochemical PAN calibration source similar to that described by Roberts et al. (2004) and Wolfe et al. (2007). We assumed that the calibrator was $93 \pm 7 \%$ efficient in converting NO to PAN (Volz-Thomas et al., 2002; Warneck and Zerbach, 1992). Calibrations were accomplished by manually switching the inlet line from the common sampling manifold to the calibrator exhaust line. A small portion of the calibrator exhaust was pulled into the sample loop and calibration samples were handled similarly to ambient samples. Multi-point calibrations were done every two weeks. We used an Airgas standard cylinder with a NO mixing ratio of $0.82 \pm 0.01 \mathrm{ppm}$ during spring 2008 . This cylinder was compared to a $10.1 \mathrm{ppm}$ National Insti- tute of Standards and Technology (NIST)-traceable ScottMarrin cylinder prior to and following the spring 2008 campaign. The concentration in the $10.1 \mathrm{ppm}$ NO cylinder was verified through an intercomparison with other NO cylinders. We used a $0.99 \pm 0.01 \mathrm{ppm}$ NO NIST-traceable ScottMarrin cylinder during spring 2009 and 2010. Prior to each campaign, the NO mixing ratio was verified in this cylinder through an intercomparison with 14 other cylinders containing a range of $\mathrm{NO}$ mixing ratios $(0.5 \mathrm{ppmv}-100 \mathrm{ppmv})$ (E. Williams, personal communication, 2010).

We estimate the accuracy of the PAN mixing ratio produced by the calibrator to be $9 \%$. This was calculated as the root sum of the squares of the error in all the calibration components, which includes the reported uncertainty in the mixing ratios of the calibration gases $(5.0 \%)$, the uncertainty of the flow controllers used to deliver the calibration gases to the calibrator $(1.7 \%, 0.89 \%, 0.29 \%$ for the three flow controllers) and the uncertainty associated with the calibrator efficiency $(7.0 \%)$. The estimated precision of the system is $3.0 \%$. This is based on repeated sampling from the calibrator at a PAN mixing ratio of $470 \mathrm{pptv}$. At this mixing ratio, which corresponds to an average peak area of 36 area units, the standard deviation of the peak areas was 1.1 area units, or $3 \%$ of the average area of the repeated samples.

We calculated uncertainty as the root sum of the squares of the precision $(3 \%)$ and the accuracy $(9 \%)$. We estimate an on-site detection limit of $\sim 15 \mathrm{pptv}$, and this corresponds to a peak height-to-baseline noise ratio of 3 . The uncertainty at levels well above the detection limit is $10 \%$. Since the detection limit is $15 \mathrm{pptv}$ and the median mixing ratio for each campaign was $>100$ pptv, most observations were well above the detection limit. The average sensitivity throughout the 2008,2009 , and 2010 campaigns was $13.9 \pm 0.7,14.1 \pm 1.3$, and $12.1 \pm 0.9$ (mean \pm 1 standard deviation) pptv per area unit.

\subsection{Description of backward trajectories}

We calculated backward trajectories to establish the transport history of the air masses impacting MBO. The results presented here are based on 10-day back trajectories initialized each hour from the summit of MBO using the Hybrid Single-Particle Lagrangian Integrated Trajectory (HYSPLIT4) model (Draxler and Rolph, 2003). These 10-day trajectories were calculated using global meteorological data from the GDAS (Global Data Assimilation System) archive, which has a time resolution of 3 hours, a spatial resolution of $1^{\circ}$ latitude by $1^{\circ}$ longitude, and a vertical resolution of 23 pressure surfaces between 1000 and $20 \mathrm{hPa}$. The trajectories were initialized at $1500 \mathrm{~m}$ above model ground level (amgl) since the GDAS model defines the terrain for the grid box containing MBO significantly below the actual altitude of Mount Bachelor. Error in HYSPLIT trajectory calculations normal to the direction of flow are $10-30 \%$ of the distance traveled after 24h (Draxler and Hess, 1998). A trajectory is 

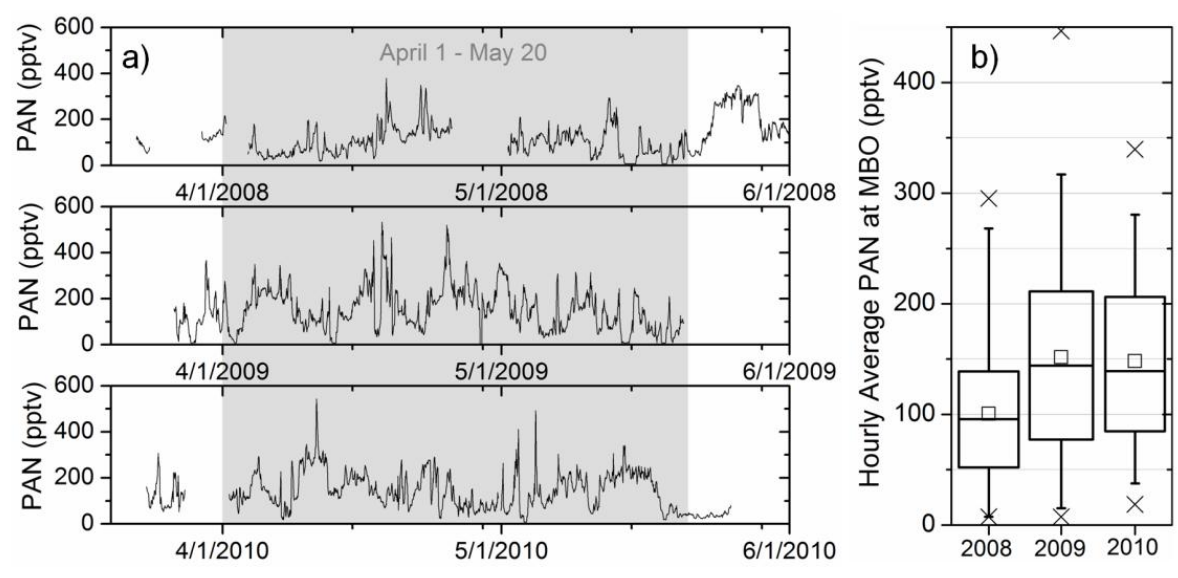

Fig. 1. (a) Hourly average PAN mixing ratios at Mount Bachelor for three spring seasons. (b) Box and whisker plots of the hourly average PAN mixing ratios for the period with overlapping data (1 April-20 May). The small squares are the seasonal means. The whiskers represent the 5th and 95th percentiles, and the x's represent the 1st and 99th percentiles.

not representative of the path of an air parcel within the BL because the parcel quickly loses its identity through mixing processes (Stohl, 1998). The HYSPLIT model is adequate to classify regional-scale air mass motions in the free troposphere.

\section{Results}

\subsection{PAN interannual variability at $\mathrm{MBO}$}

Figure 1 presents the hourly averaged PAN data for the spring 2008, 2009 and 2010 campaigns. The year-to-year overlapping period is from 1 April-20 May. All comparisons between years only use this period. General features of the PAN distribution can be seen in the time series in Fig. 1a. Fischer et al. (2010) show that synoptic scale weather systems drive the bulk of the variability in observed PAN mixing ratios at MBO, which occurs at a 3 to 4 day time scale. Not all episodes of elevated PAN are due to transport from Asia to North America; plumes containing elevated PAN mixing ratios also originate from the North American boundary layer (Fischer et al., 2010b). Yet the highest hourly averaged PAN mixing ratios observed during April 2008 and April 2009, 381 and 534 pptv respectively, were associated with plumes that originated outside of North America.

The PAN time series for April 2009 and April 2010 both had more structure than April 2008. The autocorrelation at $1 \mathrm{~h}$ was 0.53 for April 2008, 0.93 for April 2009, and 0.95 for April 2010. PAN mixing ratios below 75 pptv were also much more frequent during April 2008 than in the following years. Consequently the monthly mean for April 2008 was shifted down to $108 \mathrm{pptv}$ as compared to 174 and $150 \mathrm{pptv}$, for April 2009 and April 2010 respectively. The mean PAN mixing ratio for 1-20 May 2008 (91 pptv) was also lower than 2009 (117 pptv) and 2010 (144 pptv). To explore these differences, we divided the data based on time of day to isolate FT/down slope influence air, (12:00 a.m.-10:00 a.m. Local Time) from BL/up slope influenced air (12:00 p.m.06:00 p.m. Local Time). The differences in the monthly mean PAN mixing ratios were also present in these subsets, indicating that the variability in the PAN mixing ratios was present throughout the lower troposphere.

The box plots to the right (Fig. 1b) show the distribution of PAN for each spring. The standard deviation of the three seasonal means was $28 \mathrm{pptv}$, or about $21 \%$. The mean PAN mixing ratio for spring 2008 was significantly lower than in 2009 and 2010, though the difference between the seasonal mean in 2009 and 2010 was not significant.

\subsection{Comparison to other free tropospheric PAN observations in the Northeastern Pacific}

Aircraft and surface measurements of PAN and $\mathrm{NO}_{\mathrm{y}}$ have been conducted over the northeast Pacific over the past decade. These past measurements have primarily been campaign-based and are thus limited in temporal coverage (Kotchenruther et al., 2001b; Nowak et al., 2004; Roberts et al., 2004; Wolfe et al., 2007; Zhang et al., 2008; Kotchenruther et al., 2001a; Murphy et al., 2006). Figure 2 presents the mean PAN mixing ratios at $\mathrm{MBO}$ in the context of other recent observations over the Northeastern Pacific. Though aircraft observations have large advantages in understanding the dynamics of individual plumes, which are often intentionally followed, they do not constitute random atmospheric samples. The observations shown in Fig. 2 cover a long time span, but the large latitudinal and vertical gradients in PAN mixing ratios make previous data sets insufficient to determine the interannual variability in PAN. Direct comparison is also difficult because time lags between campaigns straddle the springtime maximum in this species (Penkett and Brice, 

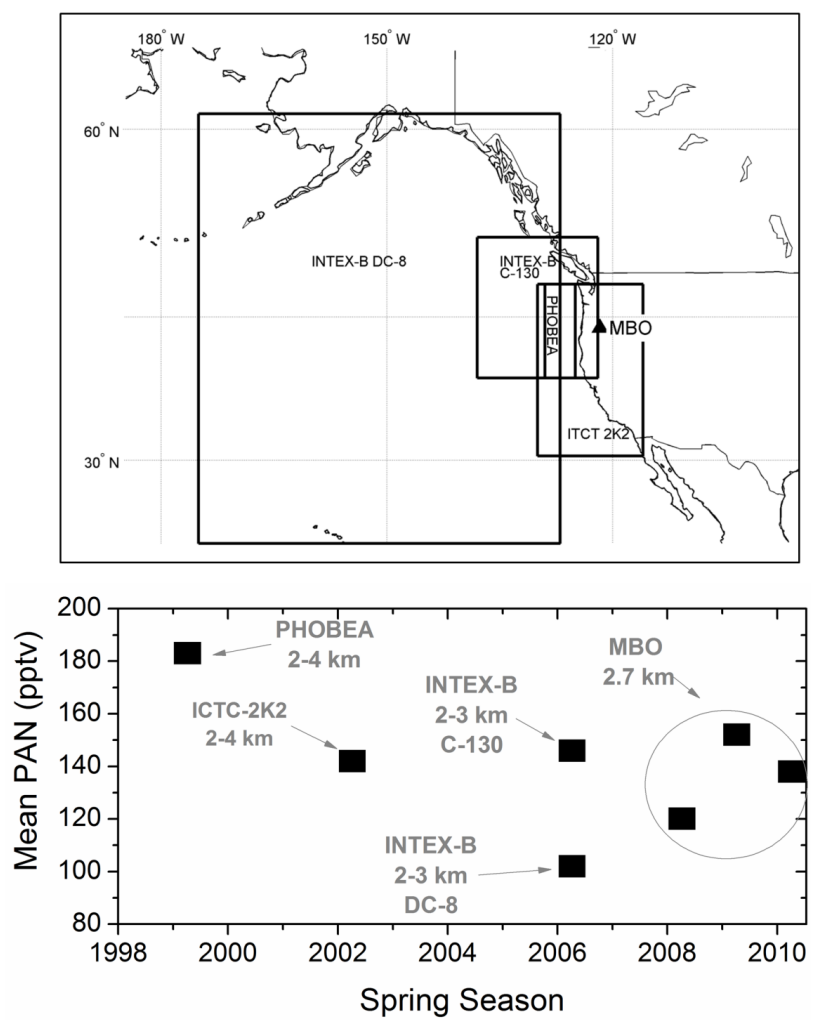

Fig. 2. Top: the location of MBO and previous airborne observations in the Eastern Pacific Region (black boxes) (Roberts et al., 2004; Zhang et al., 2008; Kotchenruther et al., 2001a). Bottom: mean PAN mixing ratios during spring from $\mathrm{MBO}$ and previous airborne campaigns. The latitude and longitude ranges shown in the map for the INTEX-B observations are associated with samples collected between 2 and $3 \mathrm{~km}$. The mean PAN mixing ratio observed at MBO during spring 2006 was 340 pptv (Wolfe et al., 2007).

1986). Spring is a transitional time for PAN in the Northern Hemisphere. PAN precursors build up in the winter and are available for PAN production during spring when photochemistry is more active (Roberts, 2007). Springtime temperatures are still cold enough to keep PAN loss rates lower than summertime.

Several general features can be seen from Fig. 2. (1) The campaign mean PAN mixing ratios observed in the eastern northeastern Pacific lower troposphere span 102-183 pptv. (2) The observed variability is due to differences in location, year, degree of plume chasing, and natural variability. (3) A consistent sampling strategy is reflected in the smaller variability at $\mathrm{MBO}$ compared to the overall variability in previous observations.

Detecting trends in trace species amidst large underlying variability presents a challenge (Weatherhead et al., 2002). Later in this paper, we use the 2008-2010 MBO data to calculate the observational requirements for detecting a possible increase in PAN mixing ratios over the northeast Pacific due to changes in Asian precursor emissions. The variability presented in Fig. 2 is driven by both natural conditions and sampling choices. The relative standard deviation (RSD) of all the campaign mean PAN mixing ratios presented in Fig. 2 is $43 \%$, while the RSD of the overlapping MBO data (1 April20 May) is $21 \%$. This illustrates that PAN observations collected at one site with one sampling method have a lower RSD. Therefore they may be more useful for investigators interested in detecting long-term changes to the photochemical environment over the northeastern Pacific.

As shown in Fig. 2, the DC-8 and C-130 sampled different regions, and this clearly contributes to differences between these two datasets. However, an intercomparison between the DC- 8 and C-130 measurements showed excellent agreement for $\mathrm{O}_{3}, \mathrm{CO}$, and $\mathrm{NO}_{2}$, but the intercomparison for PAN was relatively poor. C-130 PAN measurements were $23 \%$ higher than the DC-8. The reason for the discrepancy is not known, and this is discussed in Chen et al. (2007) and Singh et al. (2009). Regardless, substantially higher maximum PAN mixing ratios were observed during INTEX-B in 2006 than at MBO during spring 2008-2010. Instruments onboard both the C-130 and DC- 8 platforms observed PAN mixing ratios over 1 ppbv between 2 and $3 \mathrm{~km}$ (not shown); however, the peak PAN mixing ratio observed at MBO during spring 2008-2010 was 657 pptv.

\section{Drivers of PAN interannual variability}

We expect that a variety of natural and anthropogenic factors contribute to the observed PAN mixing ratios at a remote site such as MBO. Sources of PAN, as well as transport patterns, are not necessarily consistent from year-to-year. This section explores factors that could have contributed to observed variability in PAN mixing ratios: biomass burning, transport efficiency over the central and eastern Pacific, and transport temperature. The discussion provides important contextual information for future users of the MBO PAN data. In Sect. 5, we will use the variability observed in PAN at MBO to calculate the timeline for detecting a range of plausible trends in this species. This calculation assumes that the MBO PAN data, collected over 3 spring seasons, does not underestimate the true variability in this species. We show that there were year-to-year differences in several factors that are expected to drive variability in PAN mixing ratios at MBO.

\subsection{Variations in a PAN source: biomass burning emissions}

Fires peak in southeastern Russia in spring. The annual burned area exhibits strong variability in magnitude and geographical location (Vivchar, 2011). There was an early and unusually strong fire source in this region in spring 2008 due to early snow melt, and the smoke was a source of both carbonaceous aerosols and $\mathrm{O}_{3}$ precursors to the Arctic (Jacob et 
al., 2010; Warneke et al., 2009). PAN can form rapidly in boreal smoke plumes, with approximately $40 \%$ of the initial $\mathrm{NO}_{\mathrm{x}}$ emissions converted to PAN within a few hours of emission (Alvarado et al., 2010). Plumes from the Lake Baikal area, containing PAN mixing ratios up to $\sim 500 \mathrm{pptv}$, were also observed at MBO during spring 2008 (Fischer et al., 2010b, see Fig. 5). Biomass burning sources in southern Siberia have previously been shown to be an important source of many trace species to the Pacific Northwest lower troposphere (Jaffe et al., 2004). Although direct transport is less frequent, fires in Southeast Asia can also have an impact on the trace gases in the Northeastern Pacific, especially during El Nino events which typically bring drought conditions to Southeast Asia (Jaffe et al., 2001 and references within).

Though the impact of the Russian fires is evident in several plumes of elevated PAN (Fischer et al., 2010), mean PAN mixing ratios at $\mathrm{MBO}$ during spring 2008 were lower than the following two years. Mean $\mathrm{CO}$ mixing ratios at $\mathrm{MBO}$ for 1 April-20 May were 135, 133, and 159 ppbv for 2008, 2009 , and 2010, respectively. Thus the extreme fire year in southeastern Russia also did not produce anomalously high mean springtime $\mathrm{CO}$ at MBO. This is in contrast to previous work showing a strong link between seasonal mean $\mathrm{CO}$ at $\mathrm{MBO}$ and anomalously strong biomass burning in Southeast Asia (Reidmiller et al., 2009b).

Calculations presented later in the paper (Sect. 5) implicitly assume that the three years of PAN data from MBO represent the true variability in this species. The observation period at MBO did coincide with an extreme fire season in southeastern Russia. Unless relatively weak transpacific transport during spring 2008 acted to reduce the impact of these fires on western North America, the MBO PAN observations do not underestimate this driver of variability.

\subsection{Transport direction/efficiency}

The amount of PAN observed at MBO is dependent on the transport pathway of the air mass. Average background PAN mixing ratios tend to increase with altitude and latitude, though the altitudinal dependence in the lower FT is small compared to the overall range (Roberts, 2007; Roberts et al., 2004). Air that has been transported through the warmer lower troposphere, especially at low latitudes, will be depleted in PAN. Similarly, air that has been transported at higher altitudes and colder latitudes will retain more of the PAN that has formed (Nowak et al., 2004).

A number of global chemical transport models indicate that East Asian emissions make a substantial contribution to observed PAN mixing ratios at MBO (Berntsen and Karlsdottir, 1999; Fiore et al., 2010). April is the month of strongest mid-latitude transpacific transport, and the interannual variability in the transport is relatively low compared to other months of the year (Liu et al., 2005). While the interannual variability in transport is low, it is not zero (Liang et al., 2005). LRT3 Long-Range Transport Index 3 (LRT3) is an index based on monthly sea level pressure anomalies over the Pacific. It was developed using a 10-year simulation from the global chemical transport model GEOS-Chem (Liang et al., 2005). Positive LRT3 values indicate strong Pacific High and Aleutian Low pressure systems. LRT3 is correlated with the Pacific/ North American teleconnection pattern (PNA) $(R=0.69)$ (Liang et al., 2005). This index was developed using a global simulation of $\mathrm{CO}$, which is expected to be a good marker of transpacific transport due to its long lifetime ( $\sim 2$ months).

Based on the LRT3 index, April 2008 was characterized by weaker than average transpacific transport (LRT3 $=-1.2$ ). Transpacific transport was also relatively weak in April $($ LRT3 $=-0.98)$ and May $2009($ LRT3 $=-1.0)$, when springtime mean PAN mixing ratios at MBO were highest. April 2010 was characterized by relatively strong transpacific transport $(\mathrm{LRT}=1.2)$. A linear regression of six years of April and May CO at MBO versus LRT3 produces a positive relationship, but the correlation coefficient is not significantly different from zero. We focus the remainder of the discussion on variability in transport over the eastern Pacific. We summarize horizontal and vertical transport to MBO during the 2008, 2009 and 2010 spring seasons using both backward trajectories (Draxler and Rolph, 2003) and synoptic scale motion at $700 \mathrm{hPa}$ geopotential height. Reidmiller et al. (2010) showed that the vast majority of air arriving at MBO during spring has travelled north of $\sim 35^{\circ} \mathrm{N}$.

Figure 3 presents a summary of the hourly endpoints from 10-day backward HYSPLIT trajectories. A trajectory was initialized from the summit of MBO each hour for the 50day period of 1 April to 20 May, thus each plot represents 1200 individual trajectory calculations. These trajectory density plots were created by counting the number of hourly trajectory points within $200 \mathrm{~km}$ of each latitude and longitude point. With the goal of highlighting the largest differences in horizontal transport between the spring seasons, the counts were mapped using a log scale. All trajectories were run for the same amount of time, so trajectories crossing longer distances represent faster moving air masses. Figure 3 shows that the relatively high speed transport from the north, that was common in spring 2008 and 2009, was reduced in spring 2010. Unlike the previous years, the highest observed PAN mixing ratio (543 pptv hourly average on 11 April) during spring 2010 was associated with transport from the US boundary layer.

The broad features illustrated by the trajectory analysis in Fig. 3 are corroborated by NCEP/NCAR reanalysis fields (not shown). We examined composites of the following fields at $700 \mathrm{hPa}$ : geopotential height, temperature, vector winds, and vertical velocity. These fields are produced using meteorological observations from surface sites, ships, rawinsondes, aircraft, and satellites. The data assimilation system is described by Kalnay (1996), and the data can be accessed at http://www.esrl.noaa.gov/psd/data/composites/day/. The $700 \mathrm{hPa}$ geopotential heights confirm more southwesterly 


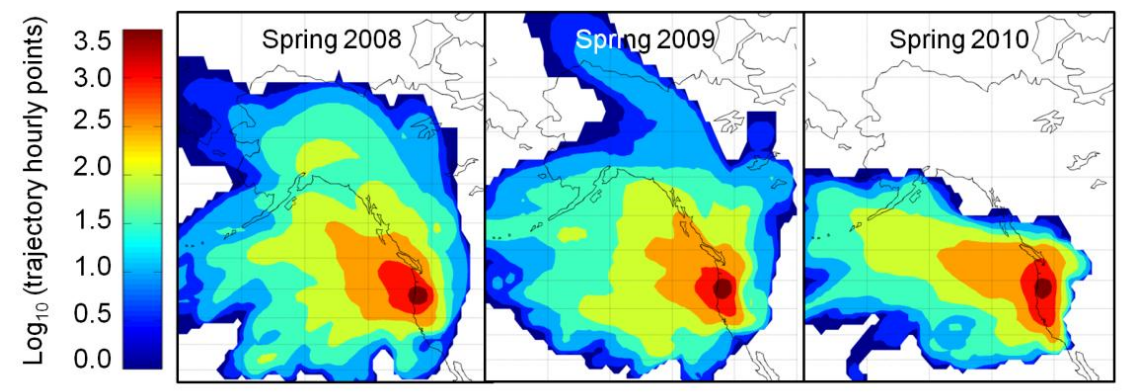

Fig. 3. Horizontal distribution of air mass transport to MBO during the period 1 April - 20 May for 2008, 2009, and 2010. These maps were created from 10-day HYSPLIT backward trajectories initialized from MBO each hour. The colors represent the number of points within a $200 \mathrm{~km}$ radius of each latitude and longitude point. Note the log scale.

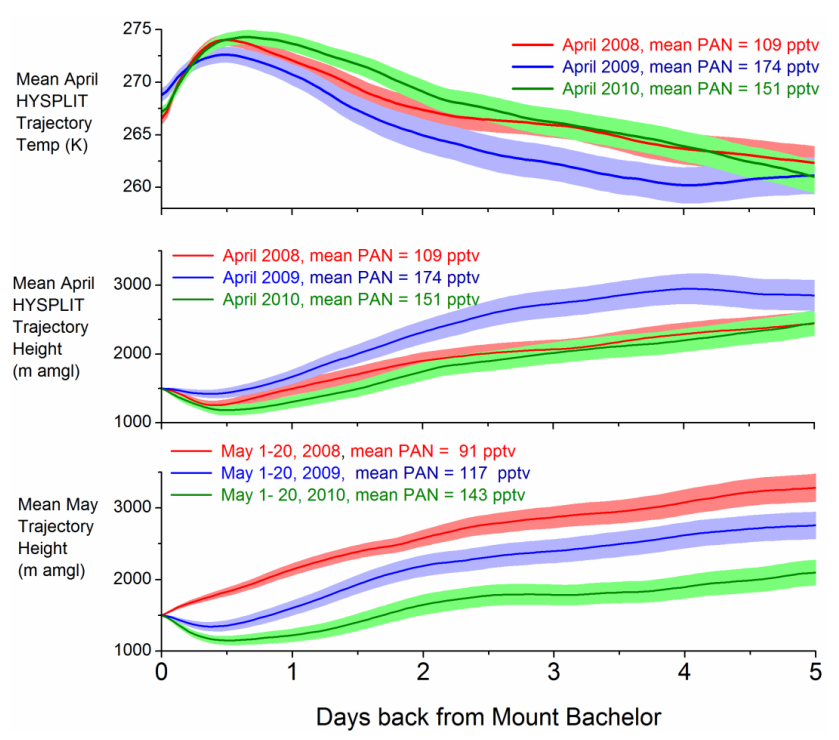

Fig. 4. Vertical distribution of air mass transport to MBO during April and May 2008 to 2010. These maps are created from 10-day HYSPLIT backward trajectories initialized from MBO each hour. Top: mean trajectory temperature for April (line) with $95 \%$ confidence interval (shading). Middle: mean trajectory height for April (line) with $95 \%$ confidence interval (shading). Bottom: as above, but for 1-20 May .

geostrophic flow during spring 2010 due to a persistent trough located off the coast. The trough extended from the northern tip of Vancouver Island to central California, and was strongest in early April 2010. It is the most notable feature in the $700 \mathrm{hPa}$ height field distinguishing spring 2010 from spring 2008 and 2009. Though the horizontal transport fields in Fig. 3 appear to be fairly similar in spring 2008 and 2009, the mean PAN observed at MBO was different between these two years. In the following section we show that differences in temperature, rather than transport direction, are consistent with observed difference in PAN mixing ratios between 2008 and 2009.

\subsection{Vertical transport}

As discussed earlier, the main loss process for PAN below $\sim 7 \mathrm{~km}$ is via thermal decomposition (Talukdar et al., 1995). Therefore we expect that the amount of PAN observed at $\mathrm{MBO}$, and the ratio of PAN to other trace gas species such as $\mathrm{CO}$ and $\mathrm{NO}_{\mathrm{x}}$, will depend on the temperature during air mass transport. As part of a detailed meteorological analysis of a major Asian plume observed at MBO on 17-18 April 2008 , we showed that a higher PAN to $\mathrm{O}_{3}$ ratio was observed under colder temperatures and a lower PAN to $\mathrm{O}_{3}$ ratio under warmer temperatures, consistent with the production of $\mathrm{O}_{3}$ from PAN decomposition during subsidence (Fischer et al., 2010b).

In Fig. 4, we have plotted the corresponding vertical distribution of air mass transport to MBO during the three spring seasons. This series of plots was created by averaging the HYSPLIT output for each hour back from MBO. Conservative estimates of the $95 \%$ confidence intervals for the means are also shaded. These intervals were calculated taking into account the autocorrelation of the trajectories by using the autocorrelation as observed at the arrival location (MBO). For example, the solid red line in the top plot in Fig. 4 is the mean temperature for 720 trajectories initialized in April 2008 ( 30 days $\times 24 \mathrm{hday}^{-1}$ ). The 720 points at hour 0 are not all independent samples because there is a high degree of autocorrelation from hour to hour, so we cannot use $N=720$ to calculate a $95 \%$ confidence interval around the mean temperature. The trajectory temperature is most correlated at MBO (hour 0) so we used the autocorrelation here to estimate a lower limit to the degrees of freedom. We used Bretherton et al. (1999) to determine the degrees of freedom which was typically 22 for each month containing 720 trajectories initialized from MBO. Thus the confidence intervals surrounding the mean along-trajectory temperature were all calculated using 22 degrees of freedom, not 720 . For example, the middle plot in Fig. 4 shows that the average altitude of air mass transport, as calculated by the HYSPLIT trajectories, was higher in 2009 than 2008 and 2010. In contrast, 
the confidence intervals show that there is no significant difference in transport altitude between April 2008 and April 2010. Though the horizontal transport fields in Fig. 3 appear to be fairly similar in 2008 and 2009, the mean temperature at which air was transported to $\mathrm{MBO}$ was different during April 2008 and 2009 (Fig. 4a), and this is consistent with the observed difference in PAN mixing ratios. It is possible to estimate PAN decomposition using the temperatures along the HYSPLIT trajectories. The mean temperature along the trajectories was an average of $3{ }^{\circ} \mathrm{C}$ colder during 2009 over approximately 5 days. The lifetime of PAN is dependent on temperature and the $\mathrm{NO}_{2} / \mathrm{NO}$ ratio because of cycling between PAN and the acetyl peroxy radical $\left(\mathrm{CH}_{3} \mathrm{CO}_{3}\right)$. Reaction of $\mathrm{CH}_{3} \mathrm{CO}_{3}$ with $\mathrm{NO}_{2}$ does not lead to a net loss of PAN, while reaction with $\mathrm{NO}$ or with other species (e.g. $\mathrm{HO}_{2}$ or $\mathrm{RO}_{2}$ ) does. An adjustment accounting for the cycling between PAN and $\mathrm{CH}_{3} \mathrm{CO}_{3}$ acts to extend the lifetime of PAN (Jacob et al., 1996; Roberts, 2007; Brasseur et al., 1999).

We used the mean temperature along the April 2008 trajectories with the monthly average PAN (175 pptv) during April 2009 to calculate the potential PAN difference due to thermal decomposition. Following Brasseur et al. (1999), we assumed a within plume $\mathrm{NO}_{2}$ to NO ratio of 1.5 , based on average plume statistics during ITCT 2K2 (Nowak et al., 2004), and calculated an effective average lifetime of PAN which accounted for cycling between $\mathrm{PAN}$ and $\mathrm{CH}_{3} \mathrm{CO}_{3}$. If all else was equal between April 2008 and 2009, this calculation suggests that more than $50 \%$ of the difference in PAN between the two months (108 versus 175 pptv) could be explained by differences in temperature during the last 5 days of transport to MBO. This is a coarse calculation because it uses mean temperature. For example, temperatures for a month could be the same, but one month could experience greater temperature extremes (high and low) and could experience a different amount of PAN dissociation. However, temperature is the only factor we were able to identify that is consistent with the higher PAN mixing ratios observed at MBO in spring 2009.

In addition to rapid transport from more northern latitudes, the HYSPLIT backward trajectories show that the air descended from higher altitudes (lower pressures) during April 2009 as compared to the 2008 and 2010 (Fig. 4b). The relatively stronger descent in April 2009 is corroborated by $700 \mathrm{mb}$ omega fields from NCEP reanalysis. Consistent with the persistent trough off the west coast mentioned earlier, the reanalysis fields also show a large region of anomalous ascent during April 2010 over western Oregon and Northern California.

With the exception of the last several hours of transport, the average along-trajectory temperature profiles were not significantly different between May 2008, 2009 and 2010 (not shown). Though the mean air mass temperatures were comparable, the trajectories show that the air descended from higher altitudes (lower pressures) during May 2008 as compared to 2009 and 2010 (Fig. 4c). Similar to April, the trajectories for May 2010 show that on average the air travelled to MBO from lower altitudes than previous years. Consistent with air mass transport from lower altitudes, a higher median water vapor mixing ratio was observed at MBO during spring 2010. The trajectories are also consistent with a region of anomalously strong ascent over Oregon present in the $700 \mathrm{mb}$ omega field during May 2010, and the region of anomalously strong descent in the same region in May 2008. Although the air reaching MBO during May 2010 was transported at significantly lower altitudes than previous years, the lower troposphere was colder than average in May 2010 over the eastern Pacific and western North America. Because of this, the differences in transport height do not correspond to significant differences in transport temperature during May.

\subsection{Other potential natural drivers of PAN variability}

Isoprene photochemistry can be a strong source of PAN (Roberts et al., 2006). Fiore et al. (2010) showed that interannual variability in isoprene emissions, which can be as large as $20-30 \%$ in summer months (Palmer et al., 2006; Müller et al., 2008), can influence seasonally averaged PAN mixing ratios downwind. However this impact is most pronounced in summer months when isoprene emissions are largest, and it is not likely to have driven the differences we observed during spring (Fiore et al., 2011, 2010).

Another factor determining the re-distribution of $\mathrm{NO}_{\mathrm{y}}$ is the vertical transport out of the East Asian and European planetary boundary layers. Aircraft campaigns have shown that variability in the amount of vertical transport out of East Asia impacts the amount of PAN that moves downwind (Roberts et al., 2004; Nowak et al., 2004; Russo et al., 2003). However Liang et al. (2005) suggest that transpacific transport is mainly dependent on the meteorology in the eastern half of the Pacific. The passage of mid-latitude cyclones, which are thought to provide the dominant pathways for pollutant export from Asia (Bey et al., 2001), constantly replenish the "pool of Asian pollution in the western Pacific" (Liang et al., 2005). It should be noted that certain scales of vertical transport are difficult to simulate in global chemical transport models.

\section{Detecting changes in PAN and $\mathrm{O}_{3}$ over North America from Increasing Asian Emissions}

Jaffe et al. (2007) hypothesized that rising $\mathrm{NO}_{\mathrm{x}}$ emissions should be detected more quickly in changes in PAN in the Northeast Pacific FT than changes in $\mathrm{O}_{3}$. This hypothesis followed from model simulations suggesting that the relative trend in PAN caused by rising Asian $\mathrm{NO}_{\mathrm{x}}$ emissions would be approximately 4 times larger than that of $\mathrm{O}_{3}$ (Zhang et al., 2007). Detecting trends in atmospheric trace species, such as $\mathrm{O}_{3}$ or PAN, depends on the size of the trend, the magnitude of the variability, and the autocorrelation of the observations (Weatherhead et al., 1998, 2002; Tiao et al., 1990). The 
Table 1. Number of springtime campaigns to detect a range of real trends in $\mathrm{PAN}_{\text {or }} \mathrm{O}_{3}$ in the Eastern Pacific lower free troposphere with a probability of $95 \%$. A real trend is indicated at the $95 \%$ confidence level.

\begin{tabular}{|c|c|c|c|c|c|c|}
\hline Change in PAN at MBO $\left(\%\right.$ year $\left.^{-1}\right)$ & 1 & 2 & 3 & 4 & 5 & 6 \\
\hline Change in $\mathrm{O}_{3}$ at $\mathrm{MBO}\left(\%\right.$ year $\left.^{-1}\right)$ & 0.25 & 0.5 & 0.75 & 1 & 1.25 & 1.5 \\
\hline Years of springtime observations to detect trend & 31 & 20 & 15 & 13 & 11 & 10 \\
\hline
\end{tabular}

data presented in Fig. 1 is the best dataset available to determine the variability and temporal autocorrelation in PAN in the lower FT over the Northeastern Pacific, and we use the MBO PAN observations to determine the observational requirements for the assessment of a trend in PAN due to rising Asian precursor emissions. We present a parallel analysis for $\mathrm{O}_{3}$, also using observations from MBO.

Zhang et al. (2008) assessed the impact of rising Asian emissions on PAN mixing ratios at MBO through two GEOSChem simulations for the INTEX-B period (April-May 2006). The first simulation used a year 2000 emissions inventory for anthropogenic emissions for Asia $\left(8^{\circ} \mathrm{N}-50^{\circ} \mathrm{N}\right.$, $80^{\circ} \mathrm{E}-150^{\circ} \mathrm{E}$ ) (Streets et al., 2003), and the second simulation used a 2006 emissions inventory for the same Asian region which was $41 \%$ higher for $\mathrm{CO}, 45 \%$ higher for nonmethane volatile organic compounds (NMVOCs), and $200 \%$ higher for $\mathrm{NO}_{\mathrm{x}}$ emissions. The estimate for $2006 \mathrm{NO}_{\mathrm{x}}$ emissions was constrained using $\mathrm{OMI} \mathrm{NO}_{2}$ data. Biomass burning emissions were not changed in the two different simulations. The higher emission scenario increased the mean PAN mixing ratio at $\mathrm{MBO}$ for the INTEX-B period from $138 \mathrm{pptv}$ to 167 pptv, or approximately $3.5 \%$ per year. Mean $\mathrm{O}_{3}$ at MBO increased from 49.6 to $52.5 \mathrm{ppbv}$, or $0.97 \%$ per year. The model estimate is consistent with the observed $+1 \%$ per year $\mathrm{O}_{3}$ trend observed by Cooper et al. (2010) and Parrish et al. (2009).

The trend estimates presented in Zhang et al. (2008) are associated with substantial uncertainty, due in a large part to uncertain emission estimates. Zhang et al. (2008) discuss uncertainties in the emission inventories and the available constraints on Asian anthropogenic $\mathrm{NO}_{\mathrm{x}}$ emissions. Though emission rates of $\mathrm{O}_{3}$ and PAN precursors are expected to continue to increase through 2020 (Ohara et al., 2007) the exact magnitude of the change is also highly uncertain. Past trends are not a predictor for future trends because many factors will influence future PAN and $\mathrm{O}_{3}$ trends including a changing climate, varying stratosphere-troposphere exchange and changes to anthropogenic and natural emissions.

Given the large uncertainty in the model-derived trend estimate, we use a range of trends with the observed variability to predict the timeline for trend detection. The following sentences describe how we applied a simple bootstrapping procedure to 4-day average PAN mixing ratios to predict when a trend in this species would be detectable at MBO. Using all

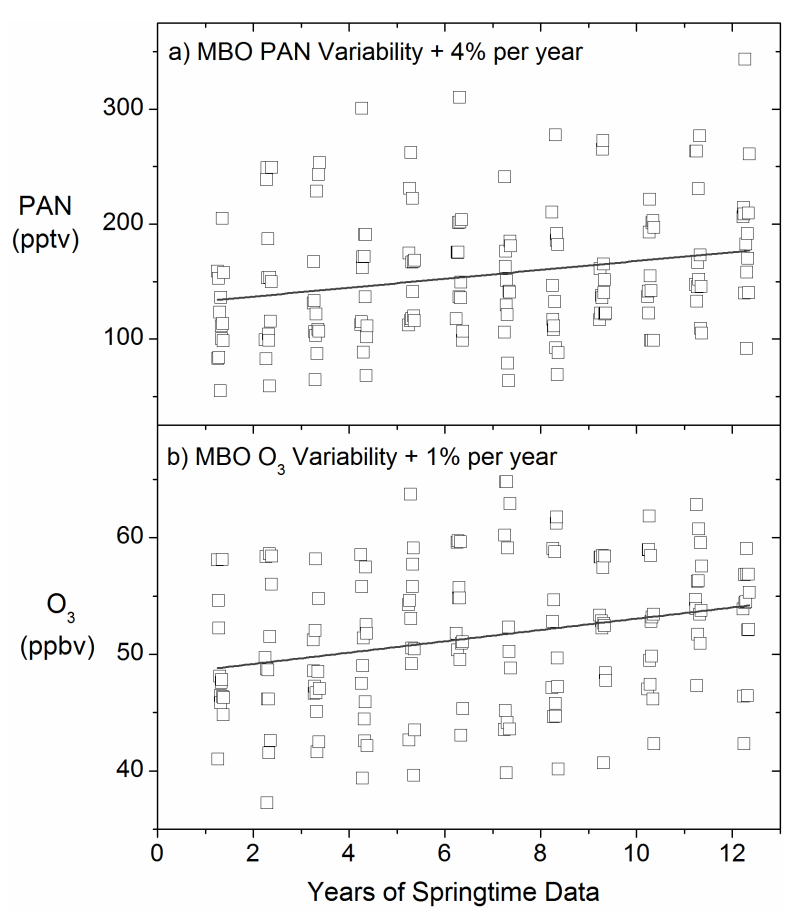

Fig. 5. (a) Random distribution of 4-day average springtime PAN mixing ratios at $\mathrm{MBO}$ for the period 2008-2010 propagated forward with a $+4 \%$ per year trend. The $\mathrm{R}^{2}$ and $\mathrm{p}$-values for this example are 0.06 and $2.8 \times 10^{-3}$, respectively. (a) Random distribution of 4-day average springtime $\mathrm{O}_{3}$ mixing ratios at $\mathrm{MBO}$ for the period 2004-2009 propagated forward with a $+1 \%$ per year trends. The $R^{2}$ and $p$-values for this example are 0.07 and $6.6 \times 10^{-4}$, respectively. The time series are examples of those used to determine the probability of trend detection. Linear fits are shown for each time series. See Table 1 for a range of PAN and $\mathrm{O}_{3}$ trends.

available springtime PAN data from MBO, we degraded the hourly averaged PAN mixing ratios shown in Fig. 1 to a time series of non-overlapping 4-day averages for each season. This choice of averaging time reduces the autocorrelation in the seasonal data sets of 4-day averages to $0.30,0.08$, and 0.43 in 2008, 2009, and 2010, respectively. This timescale also reflects the physics of the system; synoptic scale changes in transport drive 2-5 day perturbations in PAN mixing ratios (Bernsten et al., 1999; Fischer et al., 2010b). The time series in Fig. 5a was generated by randomly sampling the 
4-day average PAN mixing ratios repeatedly from all three spring seasons. The randomly selected PAN averages were then added to a hypothetical PAN trend. Thirteen 4-day average points were chosen for each spring season, to be consistent with the length of the data from the previous springtime campaigns. By sampling average PAN from the multi-year MBO dataset, we are able to include both synoptic scale and interannual variability in the calculation. We incorporate the actual variability in PAN, regardless of whether we fully understand all the drivers, so we can develop a reasonable expectation of when possible trends could be detected (Weatherhead et al., 2002). We considered a range of hypothetical future trends, and for each trend a time series like Fig. 5a was generated 1000 times. Figure $5 \mathrm{a}$ is one example. For each time series, we calculated the correlation coefficient for PAN against time as well and the corresponding t-statistic. We repeated the same bootstrapping procedure using springtime $\mathrm{MBO} \mathrm{O}_{3}$ data (Fig. 5b).

Table 1 presents the calculation described above for a range of possible $\mathrm{PAN}$ and $\mathrm{O}_{3}$ trends at $\mathrm{MBO}$, ignoring autocorrelation for this exercise. For example, thirteen years of springtime PAN data at MBO would be required to detect a real $+4 \%$ per year trend in PAN with a probability of $95 \%$, where a real trend is indicated at the $95 \%$ confidence level. The calculations show that the timescale for PAN and $\mathrm{O}_{3}$ trend detection is equivalent when the PAN trend is 4 times larger than the $\mathrm{O}_{3}$ trend. This reflects the greater variability associated with PAN, compared to $\mathrm{O}_{3}$. Interestingly the calculations of Zhang et al. (2008) suggest that the PAN and $\mathrm{O}_{3}$ trends between 2000 and 2006 may have been close to this ratio. If the trends were to continue at this same rate ( $\sim 3.5 \%$ and $\sim 1 \%$ per year, respectively), both trends could be detected in the free troposphere at MBO with about 13 years of observations. However, some care should be used in interpreting the results from the global model since there are large uncertainties associated with the emissions of both $\mathrm{NO}_{\mathrm{x}}$ and NMHCs (Zhang et al., 2008), non-linearities in the chemistry, and changes in natural sources and other process that are difficult to model (Reidmiller et al., 2009a; Wu et al., 2007). Thus long term observations of both PAN and $\mathrm{O}_{3}$ are needed to verify modeled trends. Several previous analyses of $\mathrm{O}_{3}$ and PAN trends have used data from multiple sites with complex data segregation schemes. This was done due to the fact that no single site existed in this region with long term data (Parrish et al., 2004, 2009; Cooper et al., 2010). Our analysis suggests that if the true $\mathrm{O}_{3}$ trend over western North America due to rising Asian precursor emissions is on the order of $1 \%$ per year, it could be corroborated at a site like $\mathrm{MBO}$ in a relatively short timeframe with a direct analysis of mean $\mathrm{O}_{3}$ concentrations. Further information on attribution can be obtained with data segregation techniques and chemical modeling studies.

\section{Conclusions}

We have presented the first consistent multi-year springtime measurements of PAN in the free troposphere over the US Pacific Northwest. These observations will be an important benchmark for future campaigns targeting the influence of imported $\mathrm{O}_{3}$ precursors on air quality in this region. Springtime average PAN mixing ratios at MBO vary by $\sim 21 \%$ inter-annually. We explored the impact of temperature, transpacific transport efficiency, and Siberian biomass burning on the seasonally averaged PAN mixing ratios. We show that the observations represent a range of atmospheric conditions which help to understand the variability observed in the PAN mixing ratios at $\mathrm{MBO}$. Colder air mass transport from higher altitudes in April 2009 is the only factor we found that is consistent with the higher average PAN mixing ratios observed at $\mathrm{MBO}$ during this season.

PAN observations can provide key information to attribute changes in $\mathrm{O}_{3}, \mathrm{NO}_{\mathrm{x}}$, and NMHCs. Based on estimated, but highly uncertain, emissions changes in Asia, Zhang et al. (2008) calculate a trend in PAN and $\mathrm{O}_{3}$ in the free troposphere over the northeastern Pacific of 3.5 and $1.0 \%$ per year for 2000 to 2006. If these hypothesized trends were to continue, we expect that trends in both PAN and $\mathrm{O}_{3}$ can be detected with $95 \%$ confidence with 13 years of consistent observations at a FT site.

Detection of changes in the reactive nitrogen and $\mathrm{O}_{3}$ budgets in the northeastern Pacific free troposphere will continue to be challenging without a consistent set of observations in this region. Routine free tropospheric $\mathrm{O}_{3}$ measurements are sparse, and the longest records in western North America are from weekly ozonesonde profiles from three locations, only one of which is on the west coast. There are even fewer observations of PAN, though a trend in this species is expected to be larger and would be significantly easier to attribute. Our analysis shows that if $\mathrm{O}_{3}$ precursor emissions continue to rise in East Asia at current rates, we are certain to detect a trend in a relatively short amount of time with a consistent set of observations at higher altitudes. Understanding the precursors to $\mathrm{O}_{3}$ and how they may be changing is critical to protecting environmental and human health. Estimating and attributing future tropospheric $\mathrm{O}_{3}$ concentrations will require continuation of PAN and $\mathrm{O}_{3}$ measurements at strategic locations.

Acknowledgements. Emily V. Fischer was supported by a Department of Energy Graduate Research Environmental Fellowship. Support for the Mount Bachelor Observatory was provided by the National Science Foundation under Grant ATM-0724327. We would like to thank Frank Flocke for loaning us the ECD used in the custom gas chromatograph, and Eric Williams for verifying the mixing ratio in the NO tank used for calibrations. We also wish to extend our gratitude to Lynn McMurdie for helpful discussions regarding synoptic scale transport to Mount Bachelor, to Qing Liang for providing the monthly LRT3 index, and to Lin Zhang for providing the GEOS-Chem time series of PAN at MBO. We also acknowledge the support provided by the Mount Bachelor maintenance staff. 
Edited by: W. Ward

\section{References}

Alvarado, M. J., Logan, J. A., Mao, J., Apel, E., Riemer, D., Blake, D., Cohen, R. C., Min, K.-E., Perring, A. E., Browne, E. C., Wooldridge, P. J., Diskin, G. S., Sachse, G. W., Fuelberg, H., Sessions, W. R., Harrigan, D. L., Huey, G., Liao, J., Case-Hanks, A., Jimenez, J. L., Cubison, M. J., Vay, S. A., Weinheimer, A. J., Knapp, D. J., Montzka, D. D., Flocke, F. M., Pollack, I. B., Wennberg, P. O., Kurten, A., Crounse, J., Clair, J. M. St., Wisthaler, A., Mikoviny, T., Yantosca, R. M., Carouge, C. C., and Le Sager, P.: Nitrogen oxides and PAN in plumes from boreal fires during ARCTAS-B and their impact on ozone: an integrated analysis of aircraft and satellite observations, Atmos. Chem. Phys., 10, 9739-9760, doi:10.5194/acp-10-9739-2010, 2010.

Bell, M. L., McDermott, A., Zeger, S. L., Samet, J. M., and Dominici, F.: Ozone and short-term mortality in 95 US urban communities, 1987-2000, JAMA-J. Am. Med. Assoc., 292, 23722378, 2004.

Bergin, M. S., West, J., Keating, T. J., and Russell, A. G.: Regional atmospheric pollution and transboundary air quality management, The Annual Review of Environment and Resources, 30, 1-37, 2005.

Berntsen, T. K. and Karlsdottir, S.: Influence of Asian emissions on the composition of air reaching the North Western United States, Geophys. Res. Lett., 26, 2171-2174, 1999.

Bernsten, T. J., Karlsdottir, S., and Jaffe, D.: Influence of Asian emissions on the composition of air reaching the north western United States, Geophys. Res. Lett., 26, 2171-2174, 1999.

Bey, I., Jacob, D. J., Logan, J. A., and Yantosca, R. M.: Asian chemical outflow to the Pacific in spring: Origins, pathways, and budgets, J. Geophys. Res., 106, 23,097-023,113, 2001.

Brasseur, G. P., Orlando, J. J., and Tyndall, G. S.: Atmospheric Chemistry and Global Change, Oxford University Press, New York, USA, 654 pp., 1999.

Bretherton, C. S., Widmann, M., Dymnikov, V. P., Wallace, J. M., and Blade, I.: The effective number of spatial degrees of freedom of a time-varying field, J. Climate, 12, 1990-2009, 1999.

Chan, E. and Vet, R. J.: Baseline levels and trends of ground level ozone in Canada and the United States, Atmos. Chem. Phys., 10, 8629-8647, doi:10.5194/acp-10-8629-2010, 2010.

Chen, G., Kleb, M. M., Brune, W. H., and Flocke, F. M.: An Overview of INTEX-B/MILAGRO/IMPEX Instrument and Measurement Intercomparison, Eos Trans. AGU, 88, A33A0817, 2007.

Cooper, O. R., Parrish, D. D., Stohl, A., Trainer, M., Nedelec, P., Thouret, V., Cammas, J. P., Oltmans, S. J., Johnson, B. J., Tarasick, D., Leblanc, T., McDermid, I. S., Jaffe, D. A., Gao, R., Stith, J., Ryerson, T. B., Aikin, K., Campos, T., Weinheimer, A. J., and Avery, M. A.: Increasing springtime ozone mixing ratios in the free troposphere over western North America, Nature, 463, 344-348, 2010.

Draxler, R. R. and Hess, G. D.: An overview of the HYSPLIT_4 modelling system for trajectories, dispersion, and deposition, Aust. Meteorol. Mag., 47, 295-308, 1998.
Draxler, R. R. and Rolph, G. D.: HYSPLIT (HYbrid Single-Particle Lagrangian Integrated Trajectory) Model access via NOAA ARL READY Website (http://www.arl.noaa.gov/ready/hysplit4.html), NOAA Air Resources Laboratory, Silver Spring, M.D., 2003.

Fiore, A. M., Dentener, F. J., Wild, O., Cuvelier, C., Schultz, M. G., Hess, P., Textor, C., Schulz, M., Doherty, R. M., Horowitz, L. W., MacKenzie, I. A., Sanderson, M. G., Shindell, D. T., Stevenson, D. S., Szopa, S., Van Dingenen, R., Zeng, G., Atherton, C., Bergmann, D., Bey, I., Carmichael, G. R., Collins, W. J., Duncan, B. N., Faluvegi, G., Folberth, G., Gauss, M., Gong, S. L., Haugustaine, D., Holloway, T., Isaksen, I. S. A., Jacob, D. J., Jonson, J. E., Kaminski, J. W., Keating, T. J., Lupu, A., Marner, E., Montanaro, V., Park, R. J., Pitari, G., Pringle, K. J., Pyle, J. A., Schroeder, S., Vivanco, M. G., Wind, P., Wojcik, G., Wu, S., and Zuber, A.: Multimodel estimates of intercontinental sourcereceptor relationships for ozone pollution, J. Geophys. Res., 114, D04301, doi:10.1029/2008JD010816, 2009.

Fiore, A. M., Jaffe, D., Fischer, E., Staehelin, J., Pandey, S., Steinbacher, M., Zellweger, C., and Team, H. M.: Measured and modeled PAN mixing ratios in the free troposphere, Symposium on Atmospheric Chemistry and Physics at Mountain Sites, Interlaken, Switzerland, 8-10 June, 2010, 2010.

Fiore, A. M., Levy II, H., and Jaffe, D. A.: North American isoprene influence on intercontinental ozone pollution, Atmos. Chem Phys., 11, 1697-1710, doi:10.5194/acp-11-1697-2011, 2011.

Fischer, E. V., Hsu, N. C., Jaffe, D. A., Jeong, M.-J., and Gong, S. L.: A decade of dust: Asian dust and springtime aerosol load in the US Pacific Northwest, Geophs. Res. Lett., 36, L03821, doi:10.1029/2008GL036467, 2009.

Fischer, E. V., Jaffe, D. A., Marley, N. A., Gaffney, J. S., and Marchany-Rivera, A.: Optical properties of aged Asian aerosols observed over the US Pacific Northwest, J. Geophys. Res., 115, D20209, doi:10.1029/2010JD013943 2010a.

Fischer, E. V., Jaffe, D. A., Reidmiller, D. R., and Jaegle, L.: Meteorological controls on observed peroxyacetyl nitrate (PAN) at Mount Bachelor during the spring of 2008, J. Geophys. Res., 115, D03302, doi:10.1029/20092009JD20012776, 2010b.

Flocke, F., Weinheimer, A. J., Swanson, A. L., Roberts, J. M., Schmitt, R., and Shertz, S.: On the measurement of PANs by gas chromatography and electron capture detection, J. Atmos. Chem., 52, 19-43, 2005.

Guenther, A., Karl, T., Harley, P., Wiedinmyer, C., Palmer, P. I., and Geron, C.: Estimates of global terrestrial isoprene emissions using MEGAN (Model of Emissions of Gases and Aerosols from Nature), Atmos. Chem. Phys., 6, 3181-3210, doi:10.5194/acp-63181-2006, 2006.

Heald, C. L., Jacob, D. J., Fiore, A. M., Emmons, L. K., Gille, J. C., Deeter, M. N., Warner, J., Edwards, D. P., Crawford, J. H., Hamlin, A. J., Sachse, G. W., Browell, E. V., Avery, M. A., Vay, S. A., Westberg, D. J., Blake, D. R., Singh, H. B., Sandholm, S. T., Talbot, R. W., and Fuelberg, H. E.: Asian outflow and transPacific transport of carbon monoxide and ozone pollution: An integrated satellite, aircraft, and model perspective, J. Geophys. Res., 108, 4804, doi:10.1029/2003JD003507, 2003.

Horowitz, L. W.: Past, present, and future concentrations of tropospheric ozone and aerosols: methodology, ozone evaluation, and sensitivity to aerosol wet removal, J. Geophys. Res., 111, D22211, doi:10.1029/2005JD006937, 2006.

Hubbell, B. J., Hallberg, A., McCubbin, D. R., and Post, E.: Health- 
related benefits of attaining the 8-hour ozone standard, Environ. Health Persp., 113, 73-82, 2005.

Hudman, R., Jacob, D. J., Cooper, O. R., Evans, M. J., Heald, C. L., Park, R. J., Fehsenfeld, F. C., Flocke, F. M., Holloway, J., Hubler, G., Kita, K., Koike, M., Kondo, Y., Neuman, A., Nowak, J., Oltmans, S. L., Parrish, D. D., Robert, J. M., and Ryerson, T.: Ozone production in transpacific Asian pollution plumes and implications for ozone air quality in California, J. Geophys. Res., 109, D23S10, doi:10.1029/2004JD004974, 2004.

Huntrieser, H., Heland, J., Schlager, H., Forster, C., Stohl, A., Aufmhoff, H., Arnold, F., Scheel, H. E., Campana, M., Gilge, S., Eixmann, R., and Cooper, O.: Intercontinental air pollution transport from North America to Europe: Experimental evidence from airborne measurements and surface observations, J. Geophys. Res.-Atmos., 110, D01305, doi:10.1029/2004jd005045, 2005.

Jacob, D. J., Heikes, B. G., Fan, S.-M., Logan, J. A., Mauzerall, D. L., Bradshaw, J. D., Singh, H. B., Gregory, G. L., Talbot, R. W., Blake, D. R., and Sachse, G. W.: Origin of ozone and NOx in the tropical troposphere: A photochemical analysis of aircraft observations over the South Atlantic basin, J. Geophys. Res., 101, 24,235-224,250, 1996.

Jacob, D. J., Logan, J. A., and Murti, P. P.: Effect of rising Asian emissions on surface ozone in the United States, Geophys. Res. Lett., 26, 2175-2178, 1999.

Jacob, D. J., Crawford, J. H., Maring, H., Clarke, A. D., Dibb, J. E., Emmons, L. K., Ferrare, R. A., Hostetler, C. A., Russell, P. B., Singh, H. B., Thompson, A. M., Shaw, G. E., McCauley, E., Pederson, J. R., and Fisher, J. A.: The Arctic Research of the Composition of the Troposphere from Aircraft and Satellites (ARCTAS) mission: design, execution, and first results, Atmos. Chem. Phys., 10, 5191-5212, doi:10.5194/acp-10-5191-2010, 2010.

Jaeglé, L., Jaffe, D. A., Price, H. U., Weiss-Penzias, P., Palmer, P. I., Evans, M. J., Jacob, D. J., and Bey, I.: Sources and budgets for $\mathrm{CO}$ and $\mathrm{O} 3$ in the northeastern Pacific during the spring of 2001: Results from the PHOBEA-II Experiment, J. Geophys. Res., 108, 8802, doi:10.1029/2002JD003121, 2003.

Jaffe, D. A., and Ray, J.: Increase in surface ozone at rural sites in the western US, Atmos. Environ., 41, 5,452-455,463, 2007.

Jaffe, D. A., Anderson, T. L., Covert, D., Trost, B., Danielson, J., Simpson, W., Blake, D. R., Harriss, R. C., and Streets, D.: Observations of ozone and related species in the northeast Pacific during the PHOBEA campaigns. 1. Ground-based observations at Cheeka Peak, J. Geophys. Res., 106, 7449-7461, 2001.

Jaffe, D. A., Price, H., Parrish, D., Goldstein, A., and Harris, J.: Increasing background ozone during spring on the west coast of North America, Geophs. Res. Lett., 30, 8802, doi:10/1029/2003GL017024, 2003.

Jaffe, D. A., Bertschi, I., Jaegle, L., Novelli, P., Reid, J. S., Tanimot, H., Vingarzan, R., and Westphal, D. L.: Long-range transport of Siberian biomass burning emissions and impact on surface ozone in western North America, Geophs. Res. Lett., 31, L16106, doi:1029/2004GL020093, 2004.

Jaffe, D. A., Prestbo, E., Swartzendruber, P., Weiss-Penzias, P., Kato, S., Takami, A., Hatakeyama, S., and Kajii, Y.: Export of atmospheric mercury from Asia, Atmos. Environ., 39, 3029-3038, 2005.

Jaffe, D. A., Thornton, J., Wolfe, G., Reidmiller, D., Fischer, E. V., Jacob, D. J., Zhang, L., Cohen, R., Singh, H., Weinheimer, A., and Flocke, F.: Can we detect an Influence over North America From Increasing Asian $\mathrm{NO}_{\mathrm{x}}$ Emissions?, Eos Trans, AGU, 88, Fall Meet. Suppl., Abstract A51E-04, 2007.

Kalnay, E., Kanamitsu, M., Kistler, R., Collins, W., Deaven, D., Gandin, L., Iredell, M., Saha, S., White, G., Woollen, J., Zhu, Y., Leetmaa, A., R. Reynolds, M. Chelliah, W. Ebisuzaki, W. Higgins, J. Janowiak, K. Mo, C. Ropelewski, J. Wang, R. Jenne, and D. Joseph: The NCEP/NCAR 40-Year Reanalysis Project, Bull. Amer. Meteor. Soc., 77, 437-471, 1996.

Kotchenruther, R. A., Jaffe, D. A., Beine, H. J., Anderson, T., Bottenheim, J. W., Harris, J., Blake, D., and Schmidt, R. W. H.: Observations of ozone and related species in the northeast $\mathrm{Pa}-$ cific during the PHOBEA campaigns: 2. Airborne observations, J. Geophys. Res., 106, 7463-7483, 2001a.

Kotchenruther, R. A., Jaffe, D. A., and Jaegle, L.: Ozone photochemistry and the role of peroxyacetyl nitrate in the springtime northeastern Pacific troposphere: Results from the Photochemical Ozone Budget of the Eastern North Pacific (PHOEBEA) campaign, J. Geophys. Res., 106, 28,731-728,741, 2001 b.

Lee, S., Akimoto, H., Nakane, H., Kurnosenko, S., and Kinjo, Y.: Lower tropospheric ozone trend observed in 1989-1997 at Okinawa, Japan, Geophys. Res. Lett., 25, 1637-1640, 1998.

Liang, Q., Jaeglé, L., and Wallace, J. M.: Meteorological indices for Asian outflow and transpacific transport on daily to interannual timescales, J. Geophys. Res., 110, D18308, doi:10.1029/2005JD005788, 2005.

Liu, J., Mauzerall, D. L., and Horowitz, L. W.: Analysis of seasonal and interannual variability in transpacific transport, J. Geophys. Res., 110, D04302, doi:10.1029/2004JD005207, 2005.

Müller, J.-F., Stavrakou, T., Wallens, S., De Smedt, I., Van Roozendael, M., Potosnak, M. J., Rinne, J., Munger, B., Goldstein, A., and Guenther, A. B.: Global isoprene emissions estimated using MEGAN, ECMWF analyses and a detailed canopy environment model, Atmos. Chem. Phys., 8, 1329-1341, doi:10.5194/acp-81329-2008, 2008.

Murphy, J. G., Day, D. A., Cleary, P. A., Wooldridge, P. J., and Cohen, R. C.: Observations of the diurnal and seasonal trends in nitrogen oxides in the western Sierra Nevada, Atmos. Chem. Phys., 6, 5321-5338, doi:10.5194/acp-6-5321-2006, 2006.

Nowak, J. B., Parrish, D. D., Newman, J. A., Holloway, J. S., Cooper, O. R., Ryerson, T. B., Nicks Jr., D. K., Flocke, F., Roberts, J. M., Atlas, E. L., de Gouw, J. A., Donnely, S. G., Dunlea, E., Hubler, G., Huey, L. G., Schauffler, S. M., Tanner, D. J., Warneke, C., and Fehsenfeld, F. C.: Gas-phase chemical characteristics of Asian emission plumes observed during ITCT 2K2 over the eastern North Pacific Ocean, J. Geophys. Res., 109, D23S19, doi:10.1029/2003JD004488, 2004.

NRC: Estimating mortality risk reduction and economic benefits from controlling ozone air pollution, National Academy Press, Washington DC, USA, 2008.

NRC: Global sources of local pollution, National Research Council, Washington DC, USA, 2010.

Ohara, T., Akimoto, H., Kurokawa, J., Horii, N., Yamaji, K., Yan, X., and Hayasaka, T.: An Asian emission inventory of anthropogenic emission sources for the period 1980-2020, Atmos. Chem. Phys., 7, 4419-4444, doi:10.5194/acp-7-4419-2007, 2007.

Oltmans, S. L., Lefohn, A. S., Harris, J. M., and Shadwick, D. S.: Background ozone levels of air entering the west coast of the 
US and assessment of longer-term changes, Atmos. Environ., 42, 6,020-026,038, 2008.

Palmer, P. I., Abbot, D. S., Fu, T.-Z., Jacob, D. J., Chance, K., Kuruso, T. P., Guenther, A., Weidinmyer, C., Stanton, J. C., Pilling, M. J., Pressley, S. N., Lamb, B., and Summer, A. L.: Quantifying the seasonal and interannual variability of North American isoprene emissions using satellite observations of formaldehyde column, J. Geophys. Res., 111, D12315, doi:10.1029/2005JD006689, 2006.

Parrish, D. D., Dunlea, E., Atlas, E. L., Schauffler, S. M., Donnely, S. G., Stroud, V., Goldstein, A., Millet, D. B., McKay, M., Jaffe, D., Price, H., Hess, P. G., Flocke, F., and Roberts, J. M.: Changes in the photochemical environment of the temperate North Pacific troposphere in response to increased Asian emissions, J. Geophys. Res., 109, D23S18, doi:10.1029/2004JD004978, 2004.

Parrish, D. D., Millet, D. B., and Goldstein, A. H.: Increasing ozone in marine boundary layer inflow at the west coasts of North America and Europe, Atmos. Chem. Phys., 9, 1303-1323, doi:10.5194/acp-9-1303-2009, 2009.

Paulot, F., Crounse, J. D., Kjaergaard, H. G., Kroll, J. H., Seinfeld, J. H., and Wennberg, P. O.: Isoprene photooxidation: new insights into the production of acids and organic nitrates, Atmos. Chem. Phys., 9, 1479-1501, doi:10.5194/acp-9-1479-2009, 2009.

Penkett, S. A., and Brice, K. A.: The spring maximum in photooxidants in the Northern Hemisphere troposphere, Nature, 319, 655-657, 1986.

Reidmiller, D. R., Fiore, A. M., Jaffe, D. A., Bergmann, D., Cuvelier, C., Dentener, F. J., Duncan, B. N., Folberth, G., Gauss, M., Gong, S., Hess, P., Jonson, J. E., Keating, T., Lupu, A., Marmer, E., Park, R., Schultz, M. G., Shindell, D. T., Szopa, S., Vivanco, M. G., Wild, O., and Zuber, A.: The influence of foreign vs. North American emissions on surface ozone in the US, Atmos. Chem. Phys., 9, 5027-5042, doi:10.5194/acp-9-5027-2009, 2009.

Reidmiller, D. R., Jaffe, D. A., Chand, D., Strode, S., Swartzendruber, P., Wolfe, G. M., and Thornton, J. A.: Interannual variability of long-range transport as seen at the Mt. Bachelor observatory, Atmos. Chem. Phys., 9, 557-572, doi:10.5194/acp-9-557-2009, 2009.

Reidmiller, D. R., Jaffe, D. A., Fischer, E. V., and Finley, B.: Nitrogen oxides in the boundary layer and free troposphere at the Mt. Bachelor Observatory, Atmos. Chem. Phys., 10, 6043-6062, doi:10.5194/acp-10-6043-2010, 2010.

Ridley, B. A., Shetter, J. D., Gandrud, B. W., Salas, L. J., Singh, H. B., Carroll, M. A., Hübler, G., Albritton, D. L., Hastie, D. R., Schiff, H. I., Mackay, G. I., Karechi, D. R., Davis, D. D., Bradshaw, J. D., Rodgers, M. O., Sandholm, S. T., Torres, A. L., Conden, E. P., Gregory, G. L., and Beck, S. M.: Ratios of peroxyacetyl nitrate to active nitrogen observed during aircraft flights over the Eastern Pacific Oceans and continental United States, J. Geophys. Res., 95, 10,179-110,192, 1990.

Roberts, J. M.: PAN and Related Compounds, in: Volatile Organic Compounds in the Atmosphere, edited by: Koppmann, R., Blackwell Publishing, 500, Oxford, UK, 2007.

Roberts, J. M., Flocke, F., Chen, G., De Gouw, J. A., Holloway, J. S., Hubler, G., Neuman, J. A., Nicks Jr., D. K., Nowak, J. B., Parrish, D., Ryerson, T. B., Sueper, D. T., Warnecke, C., and Fehsenfeld, F. C.: Measurement of peroxycarboxylic nitric anhydrides
(PANs) during the ITCT 2K2 aircraft intensive experiment, J. Geophys. Res., 109, D23S21, doi:10.1029/2004JD004960, 2004.

Roberts, J. M., Marchewka, M., Bertman, S. B., Goldan, P., Kuster, W., De Gouw, J. A., Warneke, C., Williams, E. J., Lerner, B., Murphy, P., Apel, E., and Fehsenfeld, F. C.: Analysis of the isoprene chemistry observed during the New England Air Quality Study (NEAQS) 2002 intensive experiment, J. Geophys. Res., 111, D23S12, doi:10.1029/2006JD007570, 2006.

Russo, R., Talbot, R., Dibb, J., Scheuer, E., Seid, G., Jordan, C., Fuelberg, H. E., Sachse, G., Avery, M., Vay, S. A., Blake, D., Blake, N. J., Atlas, E., Fried, A., Sandholm, S., Tan, D., Singh, H., Snow, J., and Heikes, B.: Chemical composition of Asian continental outflow over the western Pacific: Results from Transport and Chemical Evolution over the Pacific (TRACE-P), J. Geophys. Res., 108, 8804, doi:10.1029/2002JD003184, 2003.

Singh, H. B. and Salas, L. J.: Global distribution of peroxyacetyl nitrate, Nature, 321, 588-591, 1986.

Singh, H. B., Condon, E., Vedder, J., O’Hara, D., Ridley, B. A., Gandrud, B. W., Shetter, J. D., Salas, L. J., Huebert, B. J., Hübler, G., Carroll, M. A., Albritton, D. L., Davis, D. D., Bradshaw, J. D., Sandholm, S. T., Rodgers, M. O., Beck, S. M., Gregory, G. L., and LeBel, P. J.: Peroxyacetyl nitrate measurements during CITE 2: Atmospheric distribution and precursor relationships, J. Geophys. Res., 95, 10,163-110,178, 1990.

Singh, H. B., Viezee, W., Chen, Y., Thakur, A. N., Kondo, Y., Talbot, R. W., Gregory, G. L., Sachse, G. W., Blake, D. R., Bradshaw, J. D., Wang, L., and Jacob, D. J.: Latitudinal distribution of reactive nitrogen in the free troposphere over the Pacific Ocean in late winter/early spring, J. Geophys. Res., 103, 28,237-228,246, 1998.

Singh, H. B., Brune, W. H., Crawford, J. H., Flocke, F., and Jacob, D. J.: Chemistry and transport of pollution over the Gulf of Mexico and the Pacific: spring 2006 INTEX-B campaign overview and first results, Atmos. Chem. Phys., 9, 2301-2318, doi:10.5194/acp-9-2301-2009, 2009.

Staehelin, J., Thudium, J., Buehler, R., Volz-Thomas, A., and Graber, W.: Trends in surface ozone concentrations at Arosa (Switzerland), Atmos. Environ., 28, 75-87, 1994.

Stohl, A.: Computation, accuracy, and applications of trajectories A review and bibliography, Atmos. Environ., 32, 947-966, 1998.

Streets, D. G., Bond, T. C., Carmichael, G. R., Fernandes, S. D., Fu, Q., He, D., Klimont, Z., Nelson, S. M., Tsai, N. Y., Wang, M. Q., Woo, J.-H., and Yarber, K. F.: An inventory of gaseous and primary aerosol emissions in Asia in the year 2000, J. Geophys. Res., 108, 8809, doi:10.1029/2002JD003093, 2003.

Talukdar, R. K., Burkholder, J. B., Schmoltner, A.-M., Roberts, J. M., Wilson, R., and Ravishankara, A. R.: An investigation of the loss processes for peroxyacetyl nitrate in the atmosphere: UV photolysis and reaction with OH, J. Geophys. Res., 100, 14,163114,173, 1995.

Tanimoto, H.: Increase in springtime tropospheric ozone at a mountainous site in Japan for the period 1998-2006, Atmos. Environ., 43, 1583-1363, 2009.

Tiao, G. C., Reinsel, G. C., Daming, X., Pedrick, J. H., Zhu, X., Miller, A. J., DeLuisi, J., Mateer, C. L., and Wuebbles, D. J.: Effects of autocorrelation and temporal sampling schemes on estimates of trend and spatial correlation, J. Geophys. Res., 95, 20,507-520,517, 1990. 
Vivchar, A.: Wildfires in Russia in 2000-2008: estimates of burnt areas using the satellite MODIS MCD45 data, Remote Sensing Letters, 2, 81-90, 2011.

Volz-Thomas, A., Xueref, I., and Schmitt, R.: An automatic gas chromatograph and calibration system for ambient measurements of PAN and PPN, Environmental Science and Pollution Resources, Special Issue 4, 72-76, 2002.

Warneck, P. and Zerbach, T.: Synthesis of peroxyacetyl nitrate by acetone photolysis, Environ. Sci. Technol., 26, 74-79, 1992.

Warneke, C., Bahreini, R., Brioude, J., Brock, C. A., de Gouw, J. A., Fahey, D. W., Froyd, K. D., Holloway, J. S., Middlebrook, A., Miller, L., Montzka, S., Murphy, D. M., Peischl, J., Ryerson, T. B., Schwarz, J. P., Spackman, J. R., and Veres, P.: Biomass burning in Siberia and Kazakhstan as an important source for haze over the Alaskan Arctic in April 2008, Geophys. Res. Lett., 36, L02813, doi:10.1029/2008GL036194, 2009.

Weatherhead, E. C., Reinsel, G. C., Tiao, G. C., Meng, X.-L., Choi, D., Cheang, W.-K., Keller, T., DeLuisi, J., Wuebbles, D. J., Kerr, J. B., Miller, A. L., Oltmans, S. J., and Frederick, J. E.: Factors affecting the detection of trends: Statistical considerations and applications to environmental data, J. Geophys. Res., 103, 17,149-117,161, 1998.

Weatherhead, E. C., Stevermer, A. J., and Schwartz, B.: Detecting environmental changes and trends, Phys. Chem. Earth, 27, 399403, 2002.

Weiss-Penzias, P., Jaffe, D., Swartzendruber, P., Dennison, J. B., Chand, D., Hafner, W., and Prestbo, E.: Observations of Asian air pollution in the free troposphere at Mount Bachelor Observatory during spring of 2004, J. Geophys. Res., 111, D10304, doi:10.1029/2005JD006522, 2006.
Wolfe, G. M., Thornton, J. A., McNeill, V. F., Jaffe, D. A., Reidmiller, D., Chand, D., Smith, J., Swartzendruber, P., Flocke, F., and Zheng, W.: Influence of trans-Pacific pollution transport on acyl peroxy nitrate abundances and speciation at Mount Bachelor Observatory during INTEX-B, Atmos. Chem. Phys., 7, 53095325, doi:10.5194/acp-7-5309-2007, 2007.

Wu, S., Mickley, L. J., Jacob, D. J., Logan, J. A., Yantosca, R. M., and Rind, D.: Why are there large differences between models in global budgets of tropospheric ozone?, J. Geophys. Res., 112, D05302, doi:10.1029/2006JD007801, 2007.

Yienger, J. J., Galanter, M., Holloway, T. A., Phadnis, M. J., Guttikunda, S. K., Carmichael, G. R., Moxim, W. J., and Levy II, H.: The episodic nature of air pollution transport from Asia to North America, J. Geophys. Res., 105, 26,931-926,945, 2000.

Zhang, L., Jacob, D. J., Bowman, K. W., Jaffe, D. A., Boersma, F., and McMillan, W. W.: Recent increases in Asian emissions and consequences for transpacific ozone pollution in the United States: INTEX-B and Aura observations, Eos Trans. AGU, 88, Abstract A53H-04, 2007.

Zhang, L., Jacob, D. J., Boersma, K. F., Jaffe, D. A., Olson, J. R., Bowman, K. W., Worden, J. R., Thompson, A. M., Avery, M. A., Cohen, R. C., Dibb, J. E., Flock, F. M., Fuelberg, H. E., Huey, L. G., McMillan, W. W., Singh, H. B., and Weinheimer, A. J.: Transpacific transport of ozone pollution and the effect of recent Asian emission increases on air quality in North America: an integrated analysis using satellite, aircraft, ozonesonde, and surface observations, Atmos. Chem. Phys., 8, 6117-6136, doi:10.5194/acp-8-6117-2008, 2008. 